\title{
ABO Blood Group System and the Association with Cardiovascular Risk Factors between Men and Women with Cardiovascular Diseases-A Comparative Study
}

\author{
Rachana Katna1 Ch Srinivasa Rao² Aswin Kuma
${ }^{1}$ ESIC Medical College, Sanathnagar, Hyderabad, Telangana, India
Department of Hematology, ESIC Medical College, Sanathnagar, \\ 2Department of Hematology,
Hyderabad, Telangana, India \\ ${ }^{3}$ Department of Physiology, ESIC Medical College, Sanathnagar, \\ Hyderabad, Telangana, India \\ Ind J Car Dis Wom:2020;5:111-116
}

\begin{abstract}
Address for correspondence Rachana Katna, MBBS student, ESIC Medical College, Sanathnagar, Hyderabad, 500038, Telangana, India (e-mail: rachana.katna@gmail.com).
\end{abstract}

\begin{abstract}
Objectives The present study was designed to explore the relation between $A B O$ blood group and cardiovascular risk factors in the patients attending tertiary care hospital in South India.

Materials and Methods One hundred nine patients, each male and female with different cardiovascular diseases, were included in the study and their $A B O$ blood groups were analyzed with the cardiovascular risk factors. A detailed history was taken from all the patients regarding cardiovascular risk factors like high blood pressure, diabetes, and lipidemic. Total cholesterol, high density lipoprotein (HDL) cholesterol, low density lipoprotein (LDL) cholesterol, and serum triglycerides were determined for assessing lipidemia. Blood grouping was done using standard tube technique. Red cell and serum grouping was performed and results documented. Association between $\mathrm{ABO}$ blood groups and cardiovascular risk factors was done using chi-square test and Spearman's correlation.

Results The distribution of $A B O$ blood groups shows that blood group $O$ (41.28\%) was more common in patients followed by group B (29.36\%), group A (19.27\%), and group AB (10.09\%). One-hundred six cases (97.2\%) were Rh D positive. A statistically significant difference was observed between gender and total cholesterol, LDL cholesterol and BMI with $p$ value $<0.05$. In the study population, distribution of major cardiovascular risk factors, especially diabetes mellitus and dyslipidaemia, with $A B O$

Keywords

- ABO blood group system

- disease association

- cardiovascular risk factors blood groups shows that there was no significant difference observed between blood groups and these cardiovascular risk factors. However, statistical significance was there between blood group $\mathrm{O}$ and hypertension $(p=0.03)$.

Conclusion There was no significant difference between the blood groups and the major cardiovascular risk factors were diabetes and lipids, but there was an association between blood group $\mathrm{O}$ and hypertension.
\end{abstract}




\section{Abstract Image}

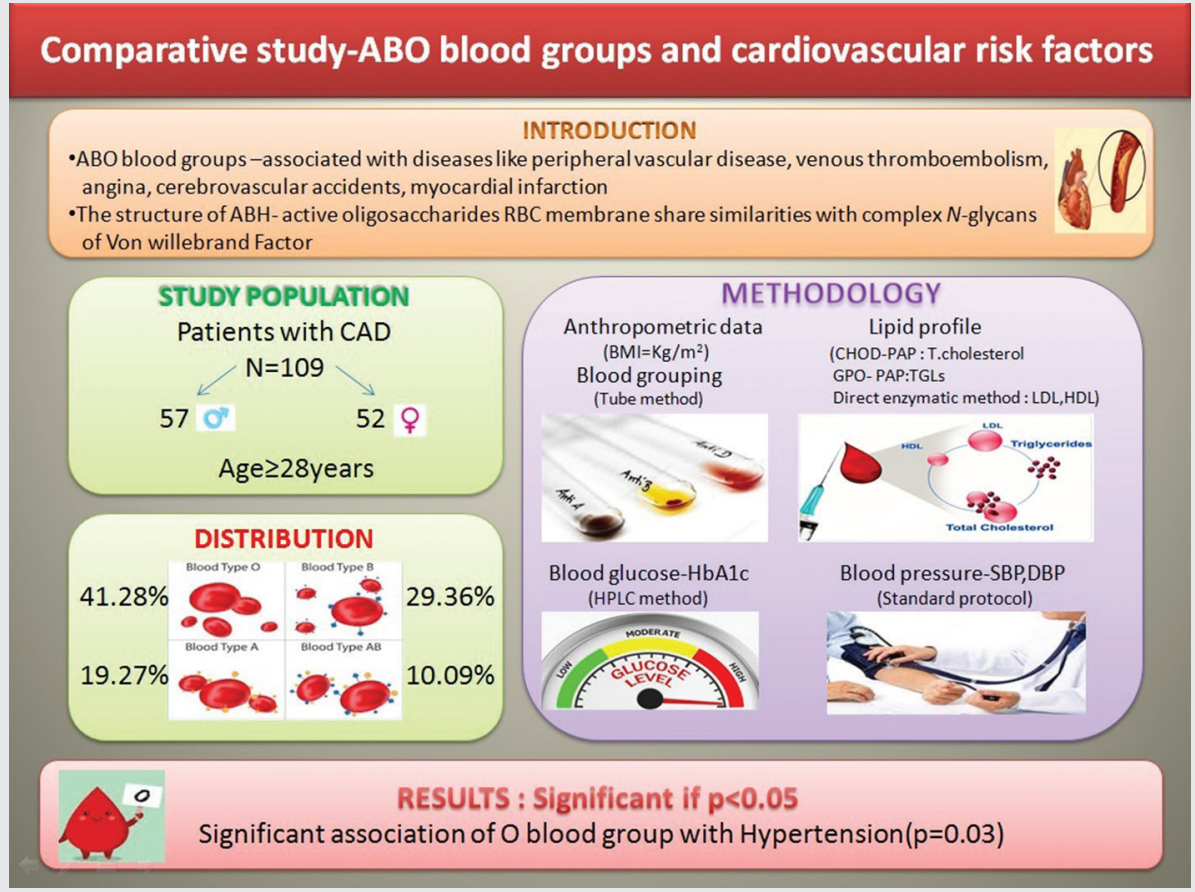

\section{Introduction}

Immunological era of blood transfusion started in 1901 with the discovery of $\mathrm{ABO}$ blood group system by Karl Landsteiner. Among 360 blood group antigens, ABO blood group system has been recognized as the major clinically significant blood group antigens, which are expressed as complex carbohydrate chains on red cell membrane. ABH-active oligosaccharides are also located on the complex $\mathrm{N}$-glycans of von Willebrand factor (VWF). Due to their presence on various cells and human tissues such as platelets, epithelium, and vascular endothelium, they are also known as "histoantigens." Several reports have suggested the association of $\mathrm{ABO}$ blood groups with diseases such as myocardial infarction, angina, peripheral vascular disease, cerebral ischemia of arterial origin, and venous thromboembolism (VTE). ABO phenotype have been recognized to have significant association with clotting anomalies like thrombotic disease more commonly seen in A blood group individuals than in $\mathrm{O}$ blood group individuals and bleeding more common in O blood group individuals than in A blood group individuals. ${ }^{1}$ About 25 to 30\% more VWF was found in plasma from non-O blood group individuals than that from $\mathrm{O}$ blood group individuals, arranged in the order $A B>A>B>O>O_{b}$ (Bombay) leading to increased prevalence of venous and arterial thrombosis in non-O blood group individuals. ${ }^{2,3}$ Further $A B O$ genotype affects the VWF quantities in plasma, with $A / O^{1}$ and $B / O^{1}$ individuals having lower VWF plasma levels than $A / A$ and $B / B$ individuals, respectively. Meta-analysis and systemic reviews confirmed association between vascular diseases and non-O phenotype. ${ }^{4}$ Genome-wide association studies further confirmed ABO blood groups as a risk factor for VTE and in a coronary artery disease.,
However, there is still a lot of variation among the results of disease association with $\mathrm{ABO}$ blood groups, as India is one of the most diverse nations ethnically in the world where distribution of blood groups varies from region to region and from one population to another. Hence, cardiovascular diseases can occur due to multiple factors; different food habits, stress levels, and working patterns in India may contribute to different levels of incidence of these lifestyle diseases among males and females. Further the risk of cardiovascular diseases is still underestimated in women and requires high-quality evidence for disease association with blood groups. Due to endogenous estrogens exposure in women, manifestation of atherosclerotic disease is assumed to be delayed during the reproductive period of life. Women's Ischemia Syndrome Evaluation study has shown that more than sevenfold increase in coronary artery risk was seen in young women with endogenous estrogen deficiency. Coronary heart disease risk worsens during menopause transition as a result of estrogen deficiency. ${ }^{7}$ Although women and men share most risk factors, cardiology guidelines should be more focused on sex-related differences and their association with cardiovascular risk factors and signs of cardiovascular diseases.

The present study was designed to explore the relationship between ABO blood group and cardiovascular risk factors among men and women patients attending tertiary care hospital in South India.

\section{Materials and Methods}

This cross-sectional study was conducted at ESICMedical College and Hospital, within the Department of Physiology in conjunction with the Department of Cardiology and Department of 
Transfusion Medicine. Group of 109 patients, both male and female with different cardiovascular diseases, were included in the study and their $\mathrm{ABO}$ blood groups were analyzed with the cardiovascular risk factors. Institutional ethics committee approval has been taken for the study. The patients were fully informed about the objectives of this study. All patients gave their informed consent to participate in the study. A close history was taken regarding cardiovascular risk factors such as high blood pressure, diabetes mellitus, and dyslipidemia. Additionally, data concerning the age of onset of menopause was also taken from the women participants. Patients in acute stages of the cardiovascular diseases and children with cardiovascular diseases were excluded from the study. Blood pressure was measured as per the standard protocol and their systolic blood pressure and diastolic blood pressure were documented. Blood glucose levels were assessed through Hemoglobin A1c (high-performance liquid chromatography method) for diabetes. Total cholesterol (CHOD-PAP method), high-density lipoprotein (HDL) cholesterol and low-density lipoprotein (LDL) cholesterol (direct enzymatic method), and serum triglycerides (GPO-PAP) were determined for assessing dyslipidemia. Anthropometric data was taken to measure height and weight. body mass index (BMI= weight $(\mathrm{kg}) /$ height $\left[\mathrm{m}^{2}\right]$ ) was calculated based on which the subjects were classified as overweight, obese, and nonobese individuals. Precisely, $3 \mathrm{~mL}$ venous sample was collected in ethylenediaminetetraacetic acid and $2 \mathrm{~mL}$ plain vacutainer for $\mathrm{ABO}$ grouping and typing. Blood grouping was done using standard tube technique as per departmental standard operating procedure. Red cell and serum grouping were performed and results were documented.

\section{Statistical Analysis}

Descriptive statistics for the categorical variables were performed. Continuous variables are expressed as mean and standard deviation. Association between ABO blood groups and cardiovascular risk factors was done using chi-squared test. Spearman's correlation was used to determine association between gender and continuous variables. All statistical analysis was performed at $5 \%$ level of significance and was considered significant if $p$-value $<0.05$. Analysis was done using SPSS version 20.0 statistical software package.

\section{Results}

During the study period, 109 patients with a diagnosis of cardiovascular disease were investigated to know the association between cardiovascular risk factors and ABO blood groups. Descriptive statistics of the study population (-Table 1 )

Table1 Descriptive statistics of study population $(n=109)$

\begin{tabular}{|l|l|}
\hline Variables & Mean \pm SD \\
\hline Age $(\mathrm{y})$ & $54 \pm 10.4$ \\
\hline Height $(\mathrm{m})$ & $1.57 \pm 0.10$ \\
\hline Weight $(\mathrm{kg})$ & $65.51 \pm 12.8$ \\
\hline
\end{tabular}

Abbreviation: SD, standard deviation. shows a mean age of 54 years (range $28-80$ years), mean height of $1.57 \mathrm{~m}$, and mean weight of $65.51 \mathrm{~kg}$.

As shown in - Fig. 1, out of 109 patients investigated, $57(52.29 \%)$ patients were male and $52(47.71 \%)$ patients were female.

The distribution of $\mathrm{ABO}$ blood groups shows ( - Fig. 2) that blood group $O(41.28 \%)$ was more common in patients followed by group B (29.36\%), group A (19.27\%), and group AB (10.09\%). One-hundred six cases (97.2\%) were Rhesus (Rh)-D positive, while three cases (2.8\%) were found to be Rh-D negative. The percentage distribution of blood groups in relation to gender is shown in $\boldsymbol{- T a b l e ~} \mathbf{2}$.

We have analyzed the distribution of cardiovascular risk factors in our study population on the basis of gender (-Table 3). The mean value of BMI, LDL cholesterol, triglycerides, and total cholesterol was on higher side in females compared with males. A statistically significant

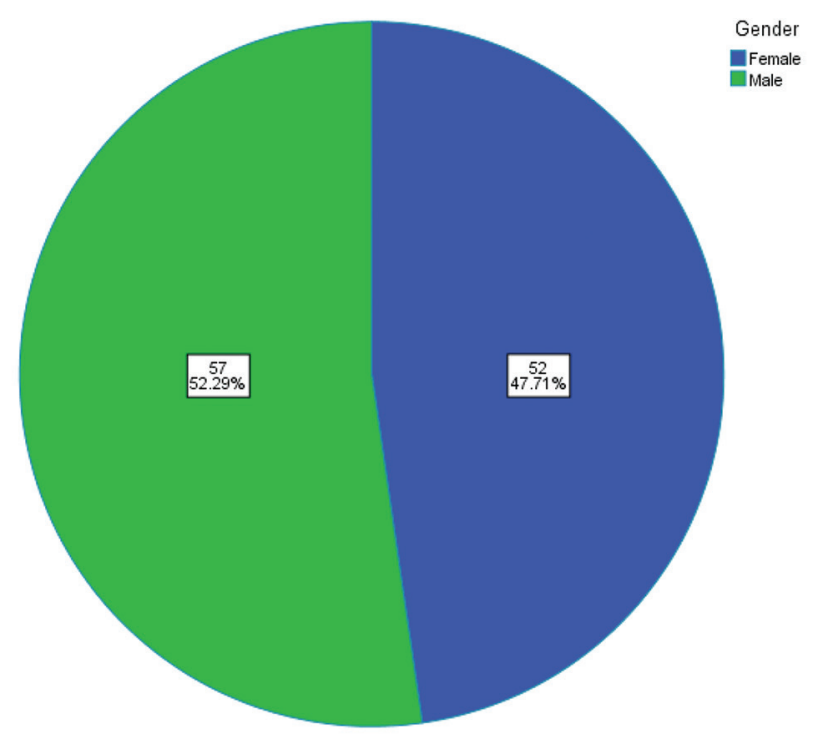

Fig. 1 Distribution of study population based on gender.

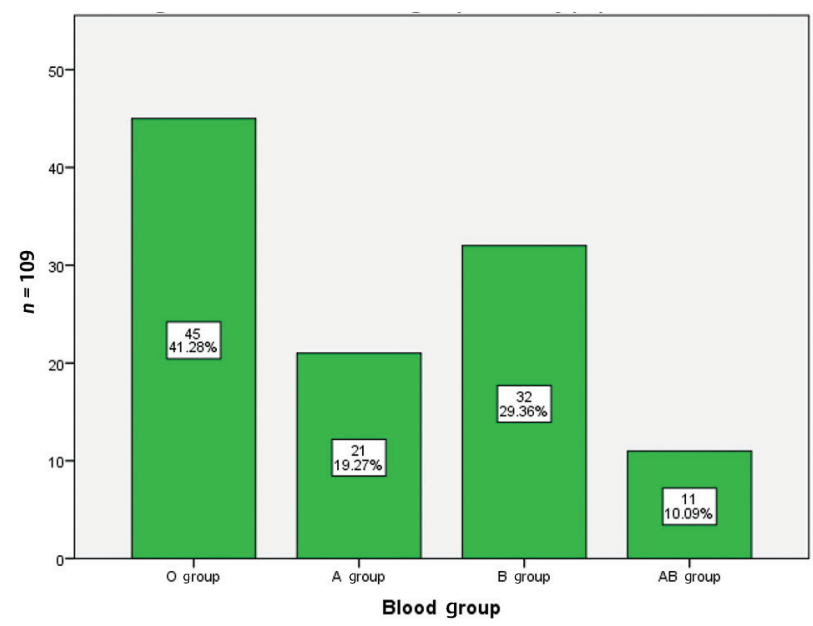

Fig. 2 Distribution of blood groups in study population. 
difference was observed between gender and total cholesterol, LDL cholesterol, and BMI with $p$-value $<0.05$.

Distribution of major cardiovascular risk factors with $\mathrm{ABO}$ blood groups ( $\mathbf{- T a b l e} \mathbf{4}$ ) in the study population shows that there was no significant difference observed between blood groups and cardiovascular risk factors under study.

The association of cardiovascular risk factors with blood groups showed no significance between $\mathrm{ABO}$ blood groups and BMI (-Table 5). There was no significant association found between lipid profile (total cholesterol, LDL cholesterol,

Table 2 Distribution of blood groups with gender

\begin{tabular}{|l|l|l|l|}
\hline \multirow{2}{*}{ Blood groups } & \multicolumn{2}{|c|}{ Gender } & \multirow{2}{*}{-Value } \\
\cline { 2 - 3 } & Male & Female & \\
\hline O group $(n=45)$ & $25(55.6 \%)$ & $20(44.4 \%)$ & \multirow{2}{*}{0.113} \\
\hline A group $(n=21)$ & $11(52.3 \%)$ & $10(47.7 \%)$ & \\
\cline { 1 - 3 } B group $(n=32)$ & $19(59.3 \%)$ & $13(40.7 \%)$ & \\
\hline AB group $(n=11)$ & $2(18.1 \%)$ & $9(81.9 \%)$ & \\
\hline Total & $57(100 \%)$ & $52(100 \%)$ & \\
\hline
\end{tabular}

Abbreviation: $n$, number of participants.

Table 3 Distribution of cardiovascular risk factors with gender

\begin{tabular}{|c|c|c|c|}
\hline \multirow{2}{*}{$\begin{array}{l}\text { Variables } \\
\text { (Mean } \pm \text { SD) }\end{array}$} & \multicolumn{2}{|c|}{ Gender } & \multirow[t]{2}{*}{$p$-Value } \\
\hline & $\begin{array}{l}\text { Male } \\
(n=57)\end{array}$ & $\begin{array}{l}\text { Female } \\
(n=52)\end{array}$ & \\
\hline $\begin{array}{l}\text { Total cholesterol } \\
\text { (mg/dL) }\end{array}$ & $\begin{array}{l}143.16 \pm \\
38.2\end{array}$ & $160.10 \pm 45.8$ & $0.028^{a}$ \\
\hline $\mathrm{HDL}(\mathrm{mg} / \mathrm{dL})$ & $37 \pm 10$ & $39 \pm 10$ & 0.245 \\
\hline LDL (mg/dL) & $92 \pm 38$ & $107 \pm 41$ & $0.040^{\mathrm{a}}$ \\
\hline $\mathrm{TGL}(\mathrm{mg} / \mathrm{dL})$ & $155 \pm 96$ & $158 \pm 100$ & 0.890 \\
\hline $\mathrm{HbA} 1 \mathrm{C}$ & $7.07 \pm 2.12$ & $6.77 \pm 2.14$ & 0.697 \\
\hline $\mathrm{SBP}(\mathrm{mm} \mathrm{Hg})$ & $132 \pm 25$ & $131 \pm 23$ & 0.885 \\
\hline DBP $(\mathrm{mm} \mathrm{Hg})$ & $87 \pm 18$ & $83 \pm 13$ & 0.272 \\
\hline BMI & $25.16 \pm 4.0$ & $28.38 \pm 7.4$ & $0.003^{b}$ \\
\hline
\end{tabular}

Abbreviations: BMI, body mass index; DBP, diastolic blood pressure; HbA1C, hemoglobin A1c; HDL, high-density lipoprotein; LDL, low-density lipoprotein; SBP, systolic blood pressure; TGL, triglyceride. ${ }^{a}$ Correlation is significant at the 0.05 level (2-tailed), SD: Standard deviation, significant by Spearman's correlation

${ }^{\mathrm{b}}$ Correlation is significant at the 0.01 level (2-tailed).
HDL cholesterol, triglycerides) of the study population and blood groups (-Tables 6-9).

The association between blood groups and hypertension (-Table 10) in the study population shows statistical significance between blood group $\mathrm{O}$ and hypertension, but no significance was seen with other blood groups. Similarly, there was no significant association found between blood groups and diabetes in study population (-Table 11).

\section{Discussion}

The aim of this cross-sectional study was to determine the association of $\mathrm{ABO}$ blood groups with various cardiovascular risk factors among cardiovascular disease patients admitted.

Table 5 Association between ABO blood groups and BMI

\begin{tabular}{|l|l|l|l|}
\hline $\begin{array}{l}\text { Blood } \\
\text { groups }\end{array}$ & $\begin{array}{l}\text { BMI } \\
\text { (normal) }\end{array}$ & $\begin{array}{l}\text { BMI } \\
\text { (overweight/obese) }\end{array}$ & $p$-Value \\
\hline $\begin{array}{l}\text { O group } \\
(n=45)\end{array}$ & $\begin{array}{l}20 \\
(44.4 \%)\end{array}$ & $\begin{array}{l}25 \\
(55.6 \%)\end{array}$ & 0.666 \\
\hline $\begin{array}{l}\text { A group } \\
(n=21)\end{array}$ & $\begin{array}{l}10 \\
(47.7 \%)\end{array}$ & $\begin{array}{l}11 \\
(52.3 \%)\end{array}$ & 0.555 \\
\hline $\begin{array}{l}\text { B group } \\
(n=32)\end{array}$ & $\begin{array}{l}11 \\
(34.3 \%)\end{array}$ & $\begin{array}{l}21 \\
(65.7 \%)\end{array}$ & 0.427 \\
\hline $\begin{array}{l}\text { AB group } \\
(n=11)\end{array}$ & $\begin{array}{l}(36.3 \%) \\
(63.7 \%)\end{array}$ & 0.740 \\
\hline
\end{tabular}

Abbreviations: BMI, body mass index, $n$, number of participants.

Table 6 Association between ABO blood groups and total cholesterol

\begin{tabular}{|l|l|l|l|}
\hline $\begin{array}{l}\text { Blood } \\
\text { groups }\end{array}$ & $\begin{array}{l}\text { Total cholesterol } \\
(<200 \mathrm{mg} / \mathrm{dL})\end{array}$ & $\begin{array}{l}\text { Total cholesterol } \\
(>200 \mathrm{mg} / \mathrm{dL})\end{array}$ & $p$-Value \\
\hline $\begin{array}{l}\text { O group } \\
(n=45)\end{array}$ & $\begin{array}{l}40 \\
(88.9 \%)\end{array}$ & $\begin{array}{l}5 \\
(11.1 \%)\end{array}$ & 0.263 \\
\hline $\begin{array}{l}\text { A group } \\
(n=21)\end{array}$ & 14 & 7 & 0.055 \\
\hline $\begin{array}{l}\text { B group } \\
(n=32)\end{array}$ & $\begin{array}{l}26.7 \%) \\
(81.2 \%)\end{array}$ & $\begin{array}{l}6 \\
(18.3 \%)\end{array}$ & 0.844 \\
\hline $\begin{array}{l}\text { AB group } \\
(n=11)\end{array}$ & 10 & 1 & 0.465 \\
\hline
\end{tabular}

Abbreviation: $n$, number of participants.

Table 4 Distribution of cardiovascular risk factors with ABO blood groups

\begin{tabular}{|l|l|l|l|l|l|}
\hline \multirow{2}{*}{$\begin{array}{l}\text { Variables } \\
(\text { Mean } \pm \text { SD) }\end{array}$} & \multicolumn{4}{|c|}{ Blood group } & \multirow{2}{*}{-Value } \\
\cline { 2 - 6 } & $\mathrm{O}(\boldsymbol{n}=\mathbf{4 5})$ & $\mathrm{A}(\boldsymbol{n}=\mathbf{2 1})$ & $\mathrm{B}(\boldsymbol{n}=\mathbf{3 2})$ & $\mathrm{AB}(\boldsymbol{n}=\mathbf{1 1})$ \\
\hline Total cholesterol $(\mathrm{mg} / \mathrm{dL})$ & $142.13 \pm 38.6$ & $160.66 \pm 45.3$ & $159.40 \pm 46.9$ & $146.72 \pm 37.4$ & 0.227 \\
\hline HDL $(\mathrm{mg} / \mathrm{dL})$ & $38.27 \pm 11.9$ & $36.62 \pm 10.1$ & $39.53 \pm 7.0$ & $39.45 \pm 11.4$ & 0.771 \\
\hline LDL $(\mathrm{mg} / \mathrm{dL})$ & $91.11 \pm 35.2$ & $103.67 \pm 36.7$ & $110.69 \pm 48.7$ & $93.82 \pm 27.0$ & 0.172 \\
\hline TGL $(\mathrm{mg} / \mathrm{dL})$ & $153 \pm 92.5$ & $170.38 \pm 91.5$ & $151.22 \pm 112.4$ & $159.91+92.3$ & 0.901 \\
\hline HbA1C & $7.02 \pm 0.1$ & $6.53 \pm 1.2$ & $7.15 \pm 2.5$ & $7.14 \pm 1.7$ & 0.758 \\
\hline SBP $(\mathrm{mm} \mathrm{Hg})$ & $131.29 \pm 23.7$ & $131.29 \pm .0$ & $130.90 \pm 23.8$ & $136.91 \pm 8.2$ & 0.908 \\
\hline DBP $(\mathrm{mm} \mathrm{Hg})$ & $86.82 \pm 19.5$ & $83.76 \pm 12.9$ & $82.87 \pm 12.9$ & $86.64 \pm 14.5$ & 0.722 \\
\hline BMI & $25.83 \pm 4.2$ & $25.7 \pm 3.9$ & $28.17 \pm 8.8$ & $27.81 \pm 6.1$ & 0.301 \\
\hline
\end{tabular}


Table 7 Association between ABO blood groups and LDL cholesterol

\begin{tabular}{|l|l|l|l|}
\hline $\begin{array}{l}\text { Blood } \\
\text { groups }\end{array}$ & $\begin{array}{l}\text { LDL cholesterol } \\
(<100 \mathrm{mg} / \mathrm{dL})\end{array}$ & $\begin{array}{l}\text { LDL cholesterol } \\
(>100 \mathrm{mg} / \mathrm{dL})\end{array}$ & $p$-Value \\
\hline $\begin{array}{l}\text { O group } \\
(n=45)\end{array}$ & $\begin{array}{l}30 \\
(66.7 \%)\end{array}$ & $\begin{array}{l}15 \\
(33.3 \%)\end{array}$ & 0.336 \\
\hline $\begin{array}{l}\text { A group } \\
(n=21)\end{array}$ & 10 & 11 & 0.261 \\
\hline $\begin{array}{l}\text { B group } \\
(n=32)\end{array}$ & $\begin{array}{l}17.6 \%) \\
(53.1 \%)\end{array}$ & $\begin{array}{l}15 \\
(46.9 \%)\end{array}$ & 0.453 \\
\hline $\begin{array}{l}\text { AB group } \\
(n=11)\end{array}$ & $\begin{array}{l}(72.8 \%) \\
(27.2 \%)\end{array}$ & 0.376 \\
\hline
\end{tabular}

Abbreviations: LDL, low-density lipoprotein; $n$, number of participants.

Table 8 Association between ABO blood groups and HDL cholesterol

\begin{tabular}{|l|l|l|l|}
\hline $\begin{array}{l}\text { Blood } \\
\text { groups }\end{array}$ & $\begin{array}{l}\text { HDL cholesterol } \\
(>50 \mathrm{mg} / \mathrm{dL})\end{array}$ & $\begin{array}{l}\text { HDL cholesterol } \\
(<50 \mathrm{mg} / \mathrm{dL})\end{array}$ & $p$-Value \\
\hline $\begin{array}{l}\text { O } \\
(n=45)\end{array}$ & 8 & 37 & 0.322 \\
$(17.8 \%)$ & $(82.2 \%)$ & 0.649 \\
\hline $\begin{array}{l}\text { A group } \\
(n=21)\end{array}$ & 2 & $\begin{array}{l}19 \\
(9.5 \%)\end{array}$ & $\begin{array}{l}(90.5 \%) \\
(93.8 \%)\end{array}$ \\
\hline $\begin{array}{l}\text { B group } \\
(n=32)\end{array}$ & 2 & 9 & 0.264 \\
\hline $\begin{array}{l}\text { AB } \\
\text { group } \\
(n=11)\end{array}$ & 2 & $\begin{array}{l}(8.2 \%) \\
(18.1 \%)\end{array}$ & $0.596)$ \\
\hline
\end{tabular}

Abbreviations: HDL, high-density lipoprotein; $n$, number of participants.

Table 9 Association between ABO blood groups and triglycerides

\begin{tabular}{|l|l|l|l|}
\hline $\begin{array}{l}\text { Blood } \\
\text { groups }\end{array}$ & $\begin{array}{l}\text { Triglycerides } \\
(<150 \mathrm{mg} / \mathrm{dL})\end{array}$ & $\begin{array}{l}\text { Triglycerides } \\
(>150 \mathrm{mg} / \mathrm{dL})\end{array}$ & $p$-Value \\
\hline $\begin{array}{l}\text { O group } \\
(n=45)\end{array}$ & $\begin{array}{l}29 \\
(64.4 \%)\end{array}$ & $\begin{array}{l}16 \\
(35.6 \%)\end{array}$ & 0.510 \\
\hline $\begin{array}{l}\text { A group } \\
(n=21)\end{array}$ & $\begin{array}{l}10 \\
(47.7 \%)\end{array}$ & $\begin{array}{l}11 \\
(52.3 \%)\end{array}$ & 0.261 \\
\hline $\begin{array}{l}\text { B group } \\
(n=32)\end{array}$ & $\begin{array}{l}21 \\
(65.7 \%)\end{array}$ & $\begin{array}{l}11 \\
(35.3 \%)\end{array}$ & 0.489 \\
\hline $\begin{array}{l}\text { AB group } \\
(n=11)\end{array}$ & 5 & $\begin{array}{l}5 \\
(45.4 \%)\end{array}$ & 0.337 \\
\hline
\end{tabular}

Abbreviation: $n$, number of participants.

In present study, the blood groups were distributed in the order of group O (41.28\%) > group B (29.36\%) > group A (19.27\%) $>$ group $\mathrm{AB}$ (10.09\%). However, the distribution was not similar between male and female in our study population. The distribution of $\mathrm{ABO}$ groups in our study is correlating with the studies conducted among blood donors in south India at Bengaluru and Kerala, respectively. ${ }^{8,9}$ However, studies from North India have described group $B$ being the most common blood group, followed by $\mathrm{O}, \mathrm{A}$, and $\mathrm{AB}$. While comparing Rh group,106 cases (97.2\%) were Rh-D positive and 3 cases (2.8\%) were Rh-D negative. Studies conducted in south India showed 91 to 95\% prevalence of Rh-D positive and 4 to $8 \%$ prevalence of Rh-D negative among blood donors. ${ }^{8,10}$ However, one study conducted on
Table 10 Association between ABO blood group and hypertension

\begin{tabular}{|l|l|l|l|}
\hline $\begin{array}{l}\text { Blood } \\
\text { groups }\end{array}$ & $\begin{array}{l}\text { With } \\
\text { hypertension }\end{array}$ & $\begin{array}{l}\text { Without } \\
\text { hypertension }\end{array}$ & $p$-Value \\
\hline $\begin{array}{l}\text { O group } \\
(n=45)\end{array}$ & $\begin{array}{l}28 \\
(62.2 \%)\end{array}$ & $\begin{array}{l}17 \\
(37.8 \%)\end{array}$ & $0.03^{\text {a }}$ \\
\hline $\begin{array}{l}\text { A group } \\
(n=21)\end{array}$ & 13 & 8 & 0.136 \\
\hline $\begin{array}{l}\text { B group } \\
(n=32)\end{array}$ & $\begin{array}{l}24.0 \%) \\
(75.0 \%)\end{array}$ & $\begin{array}{l}8 \\
(25.0 \%)\end{array}$ & 0.899 \\
\hline $\begin{array}{l}\text { AB group } \\
(n=11)\end{array}$ & 9 & $\begin{array}{l}2 \\
(81.9 \%)\end{array}$ & 0.515 \\
\hline
\end{tabular}

Abbreviation: $n$, number of participants.

aSignificance by chi-squared test.

Table 11 Association between ABO blood group and diabetes mellitus

\begin{tabular}{|l|l|l|l|}
\hline $\begin{array}{l}\text { Blood } \\
\text { Groups }\end{array}$ & $\begin{array}{l}\text { With diabetes } \\
\text { mellitus }\end{array}$ & $\begin{array}{l}\text { Without diabetes } \\
\text { mellitus }\end{array}$ & $p$-Value \\
\hline $\begin{array}{l}\text { O group } \\
(n=45)\end{array}$ & $\begin{array}{l}23 \\
(51.1 \%)\end{array}$ & $\begin{array}{l}22 \\
(48.9 \%)\end{array}$ & 0.833 \\
\hline $\begin{array}{l}\text { A group } \\
(n=21)\end{array}$ & 10 & 11 & 0.860 \\
\hline $\begin{array}{l}\text { B group } \\
(n=32)\end{array}$ & 15 & $(52.3 \%)$ & 0.762 \\
\hline $\begin{array}{l}\text { AB group } \\
(n=11)\end{array}$ & $\begin{array}{l}(46.9 \%) \\
(54.6 \%)\end{array}$ & $\begin{array}{l}17 \\
(53.1 \%)\end{array}$ & 0.739 \\
\hline
\end{tabular}

Abbreviation: $n$, number of participants.

association of $\mathrm{ABO}$ blood groups with cardiovascular risks correlated with $\mathrm{Rh}-\mathrm{D}$ negative prevalence only, in contrast with the Rh-D positive blood groups. ${ }^{11}$

Analysis of the distribution of cardiovascular risk factors with the gender showed higher mean levels of total cholesterol, LDL cholesterol, triglycerides, and BMI among females compared with males. BMI showed significant correlation $(p<0.01)$ with the gender. The prevalence of overweight/obesity is higher in females (71\%) than in males (47\%). Total cholesterol and LDL cholesterol showed significant correlation $(p<0.05)$ with the gender. No significant correlation was noticed with other cardiovascular risk variables and gender. Our observation of high prevalence of overweight and obesity agrees with the findings from previous studies. ${ }^{12}$

Cardiovascular diseases are multifactorial that includes genetic and environment factors. We have analyzed the distribution of cardiovascular risk factors among men and women with $\mathrm{ABO}$ blood groups and their association was determined. We found from the analysis that lipid profile variables had significantly different mean value among the blood groups. The mean value of total cholesterol and triglycerides was highest among group A than other groups. The mean value of HDL cholesterol was higher in group $B$ and group $A B$ and lowest in group $A$. The mean value of LDL cholesterol was higher in group $\mathrm{B}$ and lowest in group $\mathrm{O}$. With regard to $\mathrm{BMI}$, blood groups $\mathrm{B}$ and $A B$ were associated with overweight and obesity compared with group $\mathrm{O}$ and group $\mathrm{A}$, respectively. Several studies showed similar results. However, there was no significant correlation observed between blood groups, lipid profile, and BMI in our 
study population. ${ }^{12-14}$ Significant difference between the prevalence of $A B O$ blood groups and development of cardio vascular diseases was not found in few previous studies. In contrast to our study, Framingham's study and British Regional Cohort's study suggested that association of ischemic heart disease with blood group A is more when compared with other groups. Few studies done in our country also state that blood group $\mathrm{A}$ increases the risk of coronary heart disease. ${ }^{15,16}$ However, recent study from eastern part of India suggested that blood group $\mathrm{O}$ increases the risk of coronary heart disease. ${ }^{17} \mathrm{Few}$ studies also showed no statistical significant association between $\mathrm{ABO}$ blood groups and coronary artery disease. ${ }^{18}$

In the analysis of the association between the $\mathrm{ABO}$ blood groups, hypertension and diabetes, statistically significant association $(p<0.05)$ was observed only with blood group $\mathrm{O}$ and hypertension. No significant correlation was observed between other groups and hypertension in study population. Few other studies found an association between hypertension and blood groups A and B. ${ }^{19,20}$ These contrasting results probably suggest a complex interplay between the geographical area, genetic factors and environment, life style, diet, and psychosocial stress causing the cardiovascular diseases. Further studies conducted on a large scale studying an extensive list of parameters in association with blood groups would help in establishing definitive causations and high-quality evidence between blood groups and cardiovascular diseases.

\section{Limitation}

Sample size was restricted due to time constraint. The association of premenopause and postmenopause in females with cardiovascular risk factors could not be performed as the number of patients in premenopause was less compared with postmenopause. Use of lipid lowering and antihypertensive drugs among study population may also have affected the statistically significant association of ABO blood groups with cardiovascular risk factors among men and women.

\section{Conclusion}

This study showed significance of association between blood group $\mathrm{O}$ and hypertension. Further, statistically significant correlations were observed between gender and BMI, total cholesterol, and LDL cholesterol. This study results though did not show significant association between ABO blood groups with other cardiovascular risk factors; however, this study shows that blood group A and B have higher mean values with respect to cardiovascular risk factors such as lipid profile, while group B and group AB are associated with higher BMI.

\section{Audio File}

Audio file for this article is available at doi.org/10.1055/ s-0040-1714325.

\section{Conflict of Interest}

None.

\section{References}

1 Garratty G. Blood groups and disease: a historical perspective. Transfus Med Rev 2000;14(4):291-301

2 Jenkins PV, O’Donnell JS. ABO blood group determines plasma von Willebrand factor levels: a biologic function after all? Transfusion 2006;46(10):1836-1844

3 Franchini M, Capra F, Targher G, Montagnana M, Lippi G. Relationship between $\mathrm{ABO}$ blood group and von Willebrand factor levels: from biology to clinical implications. Thromb J 2007;5:14

4 Wu O, Bayoumi N, Vickers MA, Clark P. ABO $(\mathrm{H})$ blood groups and vascular disease: a systematic review and meta-analysis. J Thromb Haemost 2008;6(1):62-69

5 Trégouët D-A, Heath S, Saut N, et al. Common susceptibility alleles are unlikely to contribute as strongly as the FV and ABO loci to VTE risk: results from a GWAS approach. Blood 2009;113(21):5298-5303

6 Reilly MP, Li M, He J, et al; Myocardial Infarction Genetics Consortium; Wellcome Trust Case Control Consortium. Identification of ADAMTS7 as a novel locus for coronary atherosclerosis and association of $\mathrm{ABO}$ with myocardial infarction in the presence of coronary atherosclerosis: two genomewide association studies. Lancet 2011;377(9763) :383-392

7 Matthews KA, Meilahn E, Kuller LH, Kelsey SF, Caggiula AW, Wing RR. Menopause and risk factors for coronary heart disease. N Engl J Med 1989;321(10):641-646

8 Periyavan S, Sangeetha SK, Marimuthu P, Manjunath BK, Seema DM. Distribution of ABO and Rhesus-D blood groups in and around Bangalore. Asian J Transfus Sci 2010;4(1):41

9 John S. Prevalence of $A B O$ and Rhesus blood groups in blood donors: a study from a tertiary care centre in South Kerala. Int J Contemporary Med Res. 2017;4(11):2314-2316

10 Suresh B, Sreedhar Babu KV, Chandra Mouli P, Arun R, Jothibai DS. Distribution of ABO and Rhesus (D) blood group antigens among blood donors at a tertiary care teaching hospital blood bank in south India. J Clin Sci Res 2015;4:129-135

11 Sahita P, Anand IS, Shah M. Association of ABO blood groups with cardiovascular diseases in adult Indian population. JPTRM 2013;1(2):181-190

12 Smith S, Okai I, Abaidoo CS, Acheampong E.. Association of ABO blood group and body mass index: a cross-sectional study from a Ghanaian population. J Nutr Metab 2018;2018:8050152

13 Lutfullah AB, Quraishi NUS, Hanif A, Khan BZ, Bukhshi IM. Association of $\mathrm{ABO}$ blood groups and major ischemic heart disease risk factors. Annals of KEMU 2010;16(3):189-193

14 Amirzadegan A, Salarifar M, Sadeghian S, Davoodi G, Darabian C, Goodarzynejad H. Correlation between ABO blood groups, major risk factors, and coronary artery disease. Int J Cardiol 2006;110(2):256-258

15 Garg P, Kumar J, Choudhary R, Chawla VK. Association between ABO blood groups and myocardial infarction in Jodhpur City of India. J Bangladesh Soc Physiol 2012;7(1):13-17

16 Banerjee S, Datta UK. Relationship of ABO blood groups with ischaemic heart disease. Ind Med Gaz 2011;430-433

17 Biswas S, Ghoshal PK, Halder B, Mandal N. Distribution of ABO blood group and major cardiovascular risk factors with coronary heart disease. Biomed Res Int 2013;2013:782941

18 Madithadu A, Rajendran A, Rajashekar D, Sarella J. Association of coronary artery diseases with $\mathrm{ABO}$ and Lewis blood group phenotypes at a tertiary care teaching hospital in southern India. J Clin Diagn Res 2018;12(7):17-21

19 Sayed EL, Amin HK. ABO blood groups in correlation with hyperlipidemia, diabetes mellitus type II and essential hypertension. Asian J Pharm Clin Res. 2015;8:236-242

20 Chandra T, Gupta A. Association and distribution of hypertension, obesity and ABO blood groups in blood donors. Iran J Ped Hematol Oncol 2012;2(4):140-145 